\title{
Microalgae of the continental shelf off Paraná State, southeastern Brazil: a review of studies
}

\author{
Frederico P. BRANDINI ${ }^{1} \&$ Luciano F. FERNANDES ${ }^{2}$
}

${ }^{1}$ Universidade Federal do Paraná, Centro de Estudos do Mar (Av. Bcira Mar, s/n, 83255-000, Pontal do Sul, Pontal do Paraná, PR, Brasil)

${ }^{2}$ Universidade Federal do Paraná, Setor de Ciências Biológicas

Departamento de Botânica, Centro Politécnico

(Caixa Postal 1903, 81531-970, Curitiba, Paraná, PR, Brasil)

- Abstract: The paper reviews the taxonomic and ecological works on marine microalgae (phytoplankton and microphytobenthos) off Paraná State, Southeastern Brazil. Various studies refer to the taxonomy of benthic diatoms. Few descriptive field works in coastal and adjacent shelf waters contribute to the understanding of phytoplankton dynamics in coastal and shelf areas. Patterns of geographic distribution and changes in the phytoplankton community are described in relation to water masses and seasonal variations in the hydrographic regime. During summertime, when warm oligotrophic waters predominate over the shelf, the phytoplankton is nummerically dominated by small phytoflagellates, dinoflagellates, coccolithophorids and filaments of cyanobacteria. During wintertime, the abundance of micro-size diatoms over the shelf increase due to the dominance of cold nutrient-rich waters from the South Atlantic Central Water and wind-driven vertical circulation. The phytoplankton community off Paraná State may be classified into two categories: the diatom-dominated coastal assemblage, mainly controlled by nutrient inputs from land drainage and ressuspension of bottom sediments, and the flagellate-dominated shelf assemblage, more affected by the seasonality of local hydrographic regime.

- Resumo: O trabalho é uma revisão dos estudos taxonômicos e ecológicos das microalgas (planctônicas e bentônicas) realizados no Estado do Paraná. Á maioria dos trabalhos sobre microfitobentos são de caráter taxonômico e, basicamente, referem-se à diatomáceas bênticas sobre macroalgas ou fundos lodosos e consolidados. Poucos trabalhos contribuiram para o estudo da dinâmica espaço-temporal do fitoplâncton em áreas costeiras e de plataforma. São descritos os padrões de distribuição geográfica e as mudanças sazonais na comunidade fitoplanctônica em relação ao regime hidrográfico. No verão, quando águas quentes oligotróficas predominam na superfície, o fitoplâncton é numericamente dominado por nanoflagelados, dinoflagelados, cocolitoforídeos e cianobactérias filamentosas. No inverno, as diatomáceas do microplâncton são em geral mais abundantes devido ao domínio de águas frias ricas em nutrientes. A comunidade fitoplanctônica da plataforma paranaense pode ser classificada em duas categorias: as associações costeira, sujeitas ao aporte de nutrientes pela drenagem continental e ressuspensão do sedimento, e a comunidade da plataforma afastada da costa, mais afetada pela sasonalidade do regime hidrográfico.

- Descriptors: Phytoplankton, Microphytobenthos, Taxonomy, Paraná State, Southeastern Brazil.

- Descritores: Fitoplâncton, Microfitobentos, Taxonomia, Estado do Paraná, Região sueste do Brasil. 


\section{The Paraná littoral and plane region}

The coastline of Paraná State, Southeast Brazil, runs from north to south between $25^{\circ} 12^{\prime}$ - 58'S Lat. along the $48^{\circ} \mathrm{W}$ Long. The continental shelf is extensive, with the isobath of 200 meters starting at approximately $175-190 \mathrm{~km}$ from the coastline. The littoral plane is not extent $(10-20 \mathrm{~km}$, with a maximum of $50 \mathrm{~km}$ in the Bay of Paranaguá) due to its proximity to the Serra do Mar. Consequently, the continental drainage is small, despite the high precipitation (Bigarella, 1978), being concentrated in the inner bays of Paranaguá and Guaratuba. Heavy rains generally occur in summer, as the result of the constant stationing of polar fronts. In winter, less solar radiation, coupled with the frequent passage of a polar anticyclone, makes the atmosphere drier and colder (Bigarella, 1978; Nimer, 1990)

The littoral between the bays of Paranaguá and Guaratuba is basically formed by a single extensive sandy beach exposed to the open sea, but the inner bays are bordered by extensive mangrove forests producing organic detritus which is then transported by continental drainage and tidal currents towards the adjacent sea.

In the coastal region, the patterns of circulation on a regional scale are governed by tides, wind and precipitation patterns, draining the continent and carrying nutrients to the coastal waters. Meanwhile, it is impossible to disassociate the characteristics of the hydrographic system of the mid-shelf and the contiguous oceanic areas from the general oceanographic structure of the southern Brazil (see Emilsson, 1961) which is directly related to the seasonal dynamics of the Brazil Current and the proximity of the Subtropical Convergence.

\section{Studies in shelf and oceanic areas}

The first oceanographic studies of the Southwest Atlantic Ocean were made in the 1920's, during the expeditions of the R/V "Meteor" (Wüst, 1932; Defant, 1936) and R/V "Discovery" (Deacon, 1933, 1937). However, the data collected at that time permitted only a general and simplified vision of the water masses.

Oceanographic studies in shelf areas off Brazil were systematically begun only in the 1950's. Phytoplankton samples were collected in mid- and outcr-shclf off Paraná State within a larger sampling program covering large parts of the south and southeast regions of Brazil. Earlier informations on the physical-chemical characteristics of the water masses in this region were described by Emilsson $(1959,1961)$, based on data obtained during expeditions of the Brazilian Navy, with the corvettes "Iguatemi", "Solimōes" and the R/V "Almirante Saldanha".
The latitudinal displacements of the Subtropical Convergence, as the consequence of seasonal changes in the wind systems of the Southwest Atlantic, change completely the hydrography of the shelf. Northeasterly winds predominate during summer transporting Tropical Water (TW) from the Brazil Current (Emilsson, 1961; Miranda, 1982; Matsuura, 1986; Brandini 1990a). In winter, the southeasterly winds predominate, allowing the penetration and mixing of subantarctic waters along with shelf and tropical waters (Fig. 1). Strong gradients of temperature were observed along the shelf off Santa Catarina and Paraná, indicating the penetration of cold waters. The isohaline of $36.0 \mathrm{psu}$, which represents the limits of Tropical Water from the Brazil Current, extended along the slope during winter 1982, but it was close to the coast during summer 1984 . In the vertical plane, the main hydrographic features affecting the physical-chemical conditions of shelf waters and the planktonic community are (i) the formation of a well-defined seasonal thermocline in summer and (ii) the shelf-break upwellings (Fig 2).

Between May 1976 and June 1978 work was done on the shelf between Cabo Frio-RJ $\left(22^{\circ} \mathrm{S}\right.$ and $\left.42^{\circ} \mathrm{W}\right)$ and Cabo de Santa Marta Grande - RS ( $\left(28^{\circ} \mathrm{S}\right.$ and $\left.48^{\circ} \mathrm{W}\right)$ during various cruises of the R/V "Prof. W. Besnard" (IOUSP), supported by the Financier of Studies and Projects (FINEP). The sampling of phytoplankton material, restricted to the surface layer, included some stations off Paraná State. Aidar-Aragão et al. (1980) published the first information on the potential primary production of phytoplankton in the surface, using the C-14 technique of Steemann-Nielsen (1952) and analysis of chlorophyll-a. During the same period, Vieira \& Teixeira (1981) completed the physiological studies by means of excretion of dissolved organic material, and Soares (1983) described the taxonomic structure and the distribution of the dominant phytoplankton groups. The diatoms were abundant in neritic stations and the more significant species were Skeletonema costatum, Leptocylindrus danicus, $L$. mediterraneus, Thalassionema nitzschioides, Bacteriastrum $\mathrm{sp}$, Thalassiosira sp, Nitzschia spp and Chaetoceros spp, followed by Proboscia ( = Rhizosolenia) alata, $R$. calcaravis, R.robusta, Guinardia flaccida, Guinardia striata (= Rhizosolenia stolterfothii), Hemiaulus membranaceus and $H$. hauckii. Climacodium frauenfeldianum was significant in one of the three cruises, but associated with tropical dinoflagellates, dominated by typical neritic and oceanic representatives of the Brazil Current (e.g., Amphisolenia bidentata, Ceratium hexacanthum, C. fusus, C. karstenii, C. massiliensis, C. trichoceros, C. tripos, Diplopsalis sp., Goniodoma poliedricum, Protoperidinium grande and Pyrophacus steinii). 



Fig. 1. Geographical distributions of temperature and salinity at 5 meters in Southeast Brazil, in July-August 1982 and February-March 1984 (modified from Brandini, 1990). 



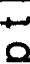

(1)
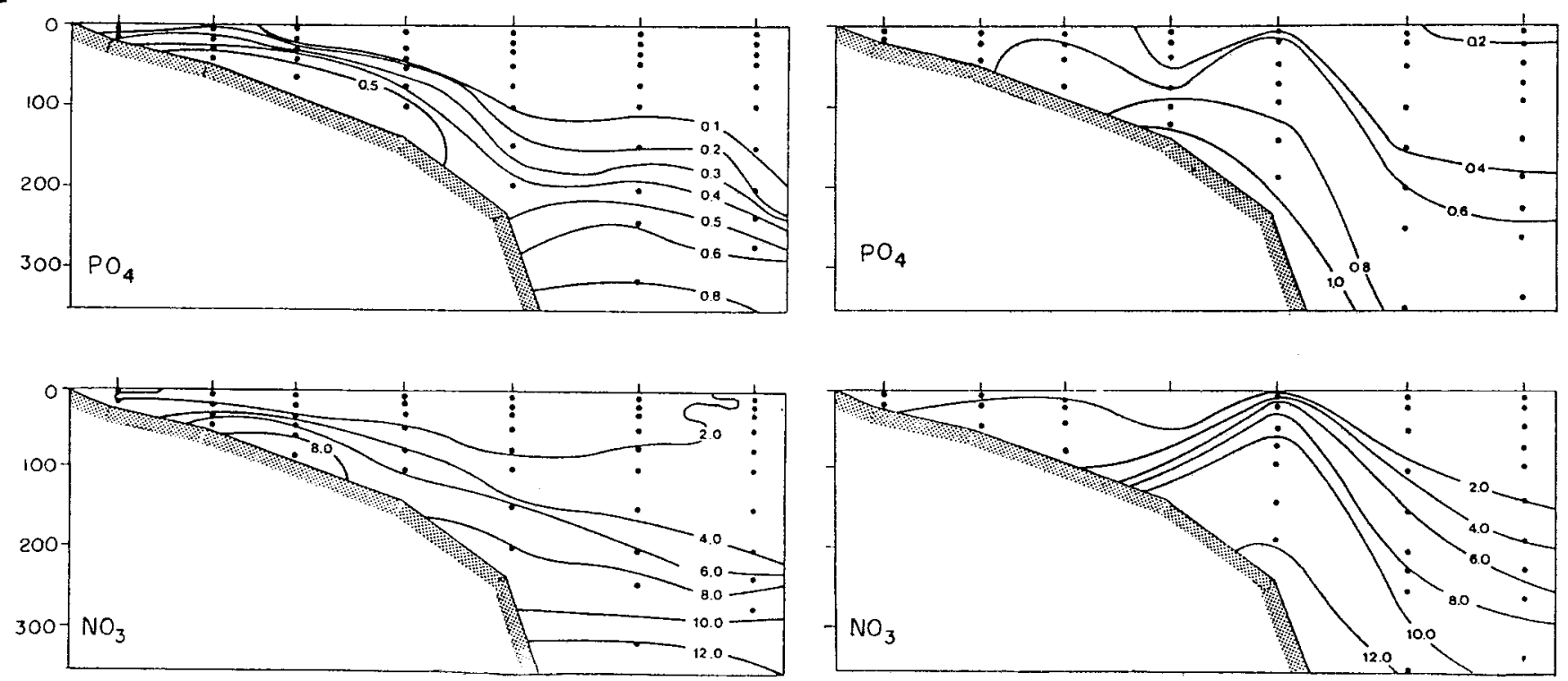

Fig. 2. Crosss-shelf distributions of temperatrure, salinity and nutrients off the Bay of Paranaguá, Paraná State, in the summer 1982 and in the winter 1983 (modified from Brandini, 1990a). 
At the end of the 1970's, the expedition "Conversut I" of the Brazilian Navy studied the hydrographical and biological aspects of the Subtropical Convergence, comprising the shelves of southern Brazil, Uruguay and part of Argentina (DHN, 1980; Hubold, 1980).

From July 1982 until November 1985, another important seasonal sampling program was carried out by the Brazilian Navy; the expeditions "SUESTE" (DHN, 1985; 1986a; 1986b, 1987) were conducted by the R/V "Almirante Saldanha", covering a sampling network of 90 oceanographic stations in each cruise, organized in 12 cross-shelf transects off São Paulo, Paraná and Santa Catarina states. During theses expeditions, the shelf-break upwelling of SACW (Mesquita et al., 1983) were detected in different seasons of the year off the Bay of Paranaguá (Brandini et al., 1989; Brandini, 1990a). These upwellings fertilize the base of the euphotic zone of the oceanic oligotrophic regions, stimulating the production of phytoplankton and the development of the pelagic ecosystem.

The collection of phytoplankton material produced data on cell density, floristic composition, photosynthetic pigments, rates of photosynthesis, estimates of potential and in situ primary production in the euphotic zone and photosynthetic characteristics of phytoplankton. The dynamics of the phytoplankton community were associated with the oceanographic structure of the region (Brandini, 1988a; Brandini, 1988b; Brandini, 1990a; Brandini et al., 1989). The expedition "Monitor IV" collected hydrographical and biological data during summer (DHN, 1989), off Rio de Janeiro, São Paulo and Paraná States.

Brandini \& Moraes (1986) and Brandini (1988b) described the patterns of geographic distribution of dominant phytoplankton groups in relation to the water masses. During winter, Brandini (1988b) showed the difference between cold water assemblages of sub-antarctic origin, dominated by diatoms, and the assemblages of the Brazil Current, dominated by cyanophyceans, coccolithophorids and dinoflagellates. A similar pattern in the neritic region was observed by Fernandes (1992) during a seasonal study in front of the Bay of Paranaguá. From these, it was deduced that seasonal changes in the structure of the phytoplankton community off Paraná State, occurred as a result of changes in the oceanographic structure. With the predominance of Tropical Water in summer, prevails a regenerative type production system (sensu Dugdale \& Goering, 1967) in which nanoplanktonic phytoflagellates, coccolithophorids and cyanophyceans are the dominant phytoplankters. During winter, the intrusion of cold and nutrient-rich waters increases the relative contribution of microplanktonic diatoms.

In the vertical plane, the structure of the phytoplanktonic community. in the euphotic zone changes in the region of the continental slope due to shelf-break upwellings. The occurrence of such upwellings has important implications on the primary production of oceanic areas, where the contribution of nutrients to the euphotic zone from deeper layers is generally limited by the presence of the permanent thermocline. The upward motions of the SACW fertilizes the base of the euphotic zone, increasing the production of phytoplankton and, consequently, that of the higher trophic levels (Brandini et al, 1988). These authors observed that the most representative modifications in the phytoplankton community were the increases in concentrations of microand nanoplanktonic coccolithophorids (Umbilicosphaera sibogae, Emiliania huxleyii, Gephirocapsa oceanica), diatoms (Pleurosigma sp, Coscinosira sp, Eucampia sp,), cyanophyceans (Oscillatoria enythraea) and dinoflagellates. The cyanophycean Trichodesmium (=Oscillatoria) occurred in the coastal areas and in the sub-surface in oceanic areas (Fig. 3a). Diatoms predominate in coastal regions, mainly in sub-surface layers due to sedimentation (Fig. 3b). Dinoflagellates and coccolithophorids were more abundant in offshore regions (Fig. $3 \mathrm{c}$ and d), associated with the shelf-break upwellings of the South Atlantic Central Water (Fig. 3e).

The photosynthetic rates in the euphotic zone and its seasonal variation were attributed to changes in the hydrography and in the taxonomic structure of phytoplankton (Brandini, 1988a, 1988b, 1990a). Brandini (1990b) estimated the primary production rates in the coast $\left(0.04-0.32 \mathrm{gC} / \mathrm{m}^{2} /\right.$ day $)$ in the intermediate shelf $(0.13$ - $0.45 \mathrm{gC} / \mathrm{m}^{2} /$ day), and in the oceanic $(0.10-0.45$ $\mathrm{gC} / \mathrm{m}^{2} /$ day) regions, and compared the potential organic production in the southeastern Brazil with data obtained in other seas. In the same work, the photosynthetic characteristics of the phytoplanktonic community were described during the stratification periods of summer, through the relations between the rates of photosynthesis and light, and by observing photo- adaptations occurring in the development of communities physiologically distinct throughout the euphotic zone.

\section{Studies in the coastal region}

Since the end of the 1950's, many works have contributed to the knowledge of diatoms in the coastal regions between the Bays of Paranaguá and Guaratuba 

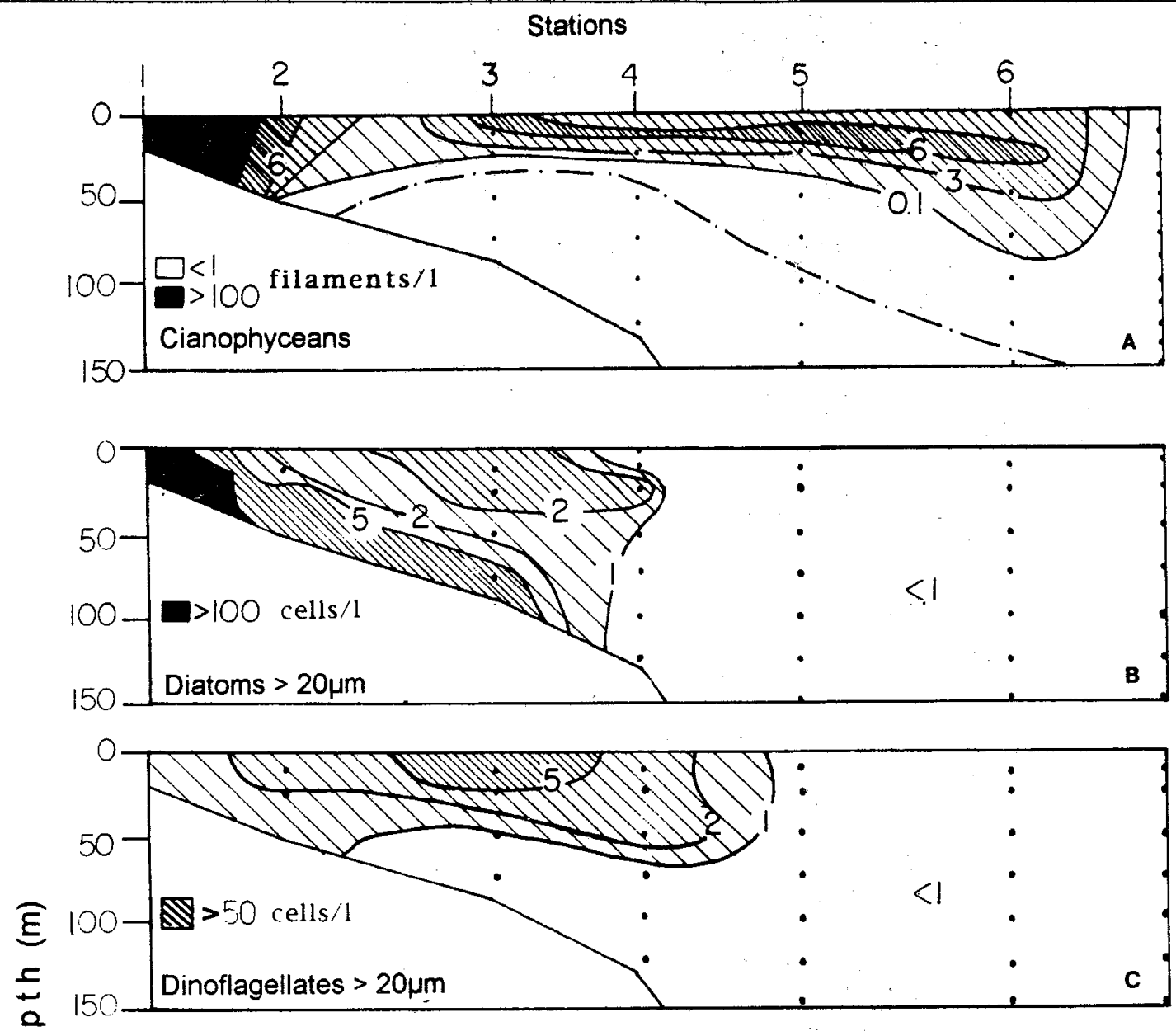

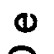
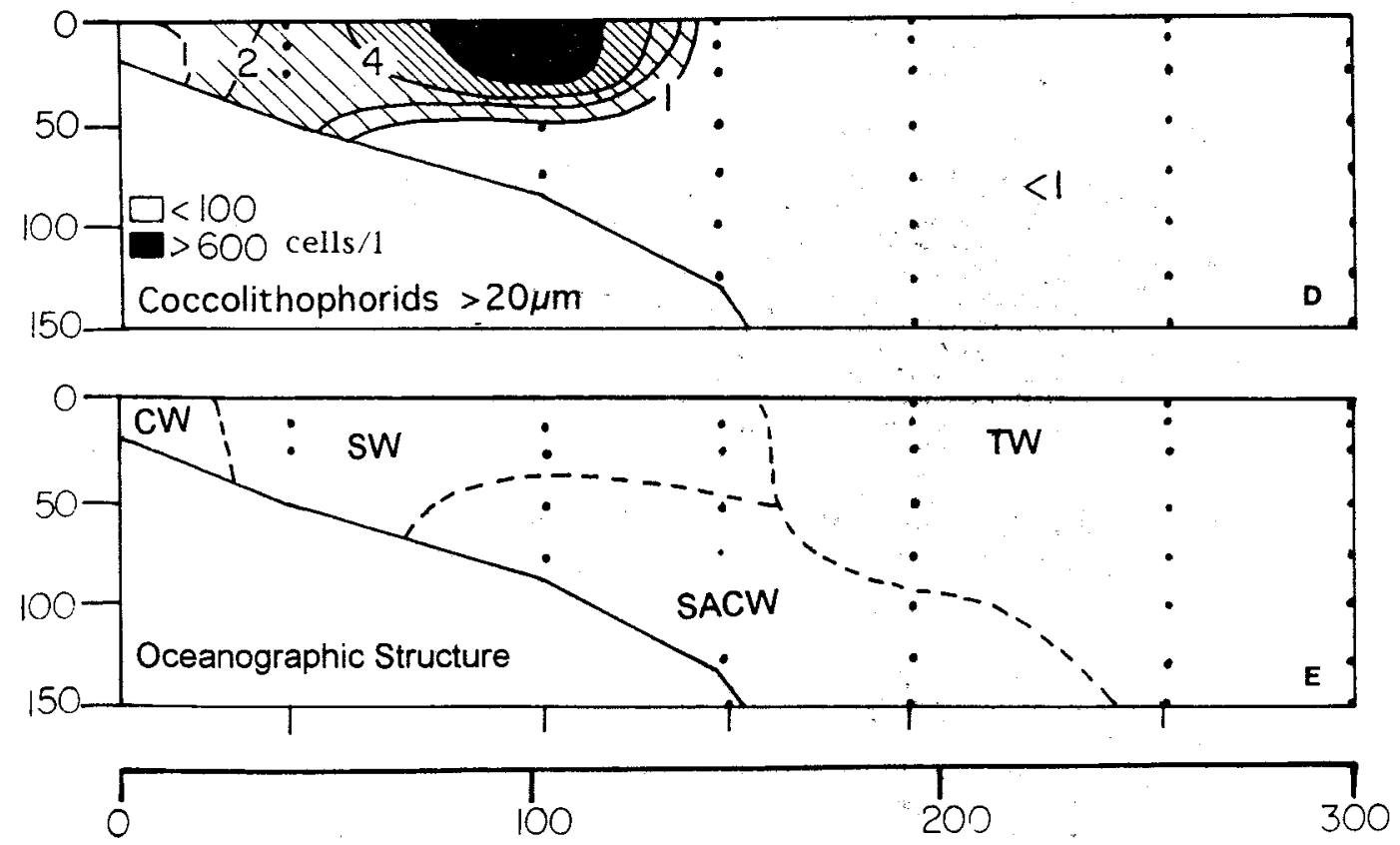

Distance $(\mathrm{Km})$

Fig. 3. Cross-shelf distribution of the phytoplankton community and the vertical oceanographic structure off the Bay of Paranaguá, Paraná State, in November of 1987. CW: coastal waters; TW: Tropical Water; SACW: South Atlantic Central Water. Multiply numerical labels of isolines in (A), (B) and (C) by 10, and in (D) by 100 (modified from Brandini, 1989). 
(Moreira Filho \& Fernandes, 1958; Moreira-Filho, 1959; Moreira-Filho, 1961; Moreira-Filho \& Kutner, 1962; Moreira Filho \& Mômoli, 1962; Moreira-Filho, 1968; Aidar, 1970; Moreira-Filho et al., 1975; Moreira-Filho \& Valente-Moreira, 1979; Moreira-Filho \& Valente-Moreira, 1980; Valente-Moreira \& Moreira-Filho, 1981; Oliveira, 1983; Oliveira, 1984; Moreira-Filho \& Valente-Moreira, 1984; Valente-Moreira et al., 1985; Valente-Moreira, 1987; Cunha, 1989; Moreira-Filho et al., 1990).

The main objectives of these works were to perform floristic and taxonomic surveys of diatoms in the Paraná coast. Moreira-Filho (1959) began by publishing the first information about epiphytic microalgae on Sargassum cymosum collected from the beach of Caiobá. In this work, 31 species of diatoms and two species of silicoflagellates were identified. Moreira-Filho \& Kutner (1962) studied the community of diatoms in sediments of Alexandra mangrove (Bay of Paranagua), identifying various planktonic species. A series of works followed, surveying the floristic of epiphytic microalgae on macroalgae (Moreira-Filho et al., 1977; Moreira-Filho \& Valente-Moreira, 1980; Valente-Moreira et al., 1980; Moreira-Filho \& Valente-Moreira, 1981; Paula, 1990), in shell deposits (Hurt \& Blasi, 1960; Moreira- Filho \& Mômoli, 1962) and in the digestive tract of invertebrates (Moreira-Filho, 1960; Valente-Moreira et al., 1994) and in fish (Valente-Moreira et al., op.cit.). The quantitatively most significant species were Achnanthes brevipes, A.longipes, Biddulphia pulchella, Cocconeis heteroidea, C. pellucida, C. scutellum, Grammatophora marina, G. oceanica, Licmophora abreviata, Mastogloia binotata, M. crucicola, M. splendida, Paralia sulcata and Synedra tabulata. Cunha (1989) described the temporaly variations in the structure of diatom community in the Galheta Channel, Bay of Paranaguá, on a seasonal scale. Moreira-Filho et al., (1990) performed a survey of diatoms identified in the whole State of Paraná, noting the occurrence of 636 species distributed in 115 classes, surpassing all the other groups of phytoplankton. In relation to benthic microalgae in the neritic area, it is difficult to establish any pattern of dominance and seasonal variation, since few works have been performed in Paraná. Meanwhile, recent investigations of Brandini et al. (in preparation) and Pellizzari $^{1}$ (1994) on the seasonal dynamics of the periphitic community in artificial substrates in the Bay of Paranaguá supply the first indications that they could

(1) Pellizzari, F. M. 1994. Ecologia do perifíton da Baía de Paranaguá, Paraná. In: EVENTO DE INICIAÇĀO CIENTÍFICA da Universidade Federal do Paraná (EVINCI - 94/resumos). Anais. Curitiba, UFPR/PRPPG, p. 121. assume a major role in the local ecosystem, by-passing phytoplanktonic biomass in certain sections of the bay, besides becoming available for the planktonic community (e.g. Cylindrotheca closterium and Pleurosigma sp). These authors noted the dominance of the diatom Navicula $\mathrm{sp}$ during rainy periods of summer, followed by Melosira sp, Coscinodiscus sp, Thalassiosira sp, Cylindrotheca closterium, Licmophora sp, Nitzschia aff. longissima and Pleurosigma sp (Fig.4), suggesting that the production of the community is controlled mainly by temperature. Concentrations of chlorophyll-a were in accordance with diatom densities. Fernandes (1992) studied the annual variation of phytoplankton on the continental shelf off the Bay of Paranaguá and recorded the presence of various benthic species in the water column, possibly due to resuspension by tidal and wind-induced turbulence. The most significants were Cyclotella stylonum, Paralia sulcata (mainly), Anorthoneis eurystoma, Delphineis surirella, Rhaphoneis amphiceros and Thalassiosira spp (3 species of valvar diameter inferior to $20 \mu \mathrm{m}$, coated with grains of sediment). There also occurred the epiphytes Biddulphia sp, Licmophora ehrenbergii, L. flabellata and Podocystis adriatica, and the planktonic genus Chaetoceros, which forms benthic resting-spores.

Since the 1980's works have been initiated in the Bay of Paranaguá with the purpose of studying the patterns of spatial and temporal variation of phytoplankton in relation to hydrographic and climatological parameters. The preliminary works concentrated on the analysis of daily variations of phytoplankton concentration and hydrographic parameters in relation to tides (Oliveira ${ }^{2}$ et al., 1983; Freitas, 1989). Brandini (1985a) described the changes in the phytoplanktonic community structure in a fixed station, in relation to pluviosity. Brandini (1985b) and Brandini et al. (1988) studied the seasonal variation and the spatial distribution of chlorophyll-a and basic hydrographic parameters within the Bay of Paranaguá.

Recently, besides the local climatology, the annual variation studies described the effects of the hydrographic regime in the adjacent shelf on the seasonal dynamics of phytoplankton in the bay (Rezende \& Brandini ${ }^{3}$, 1988; Rebello \& Brandini, 1990; Fernandes, 1992; Brandini \&

(2) Oliveira, C.; Dortas, E. M.; Sert, M. A.; Soares, F. S. \& Brandini, F. P. 1983. Variaçâo nictemerai do fitoplâncton da Baía de Paranaguá. In: SIMPÓSIO DE ESTAGIÁROS, 3. Resumos. Londrina, 1983. Fund. Univ. Estadual de Londrina, p. 5.

(3) Rezende, K. R. V. \& Brandini, F. P. 1988. Variaçāo temporal do fitoplâncton em um ponto fixo da praia de Pontal do Sul (Paraná). In: ENCONTRO BRASII.EIRO DE PLÂNCTON, 3. Resumos. Universidade Federal do Paraná. Centro de Biologia Marinha, 1988. p. 45. 




$1993-1994$

Fig. 4. Seasonal variation in the abundance of benthic diatoms in external sections of the Bay of Paranaguá, Paraná State. Abundance is expressed in terms of accumulation of cells and chlorophyll-a per area, after 7 days of submersion of artificial substrates (from Brandini et al. 1985).

Thamm, 1994). As a basis for these works, it was noted that the structure of the microalgae community is dominated by diatoms (see below) in summer, when occurs an enrichment of the water column with inorganic nutrients due to higher precipitation (Brandini, 1985a) (Fig. 5). Meanwhile, the turbulence generated by the stronger winds of winter, resuspending nutrients from the bottom, could also increase the density of diatoms in the coastal areas adjacent to the Bay of Paranaguá, with a significant contribution of benthic species such as Paralia sulcata, Delphineis surirella and Cyclotella stylorum (Fernandes, 1992). During winter, the presence of cold water species, such as Bacteriastrum hyalinum, B. varians, Eucampia comuta, Lauderia annulata, Detonula pumila (=Schroederella delicatula), Thalassiosira punctigera, Thalassiosira tumida, Thalassiothrix mediterranea, Dinophysis rotundata, Oxyphysis oxytoxoides and Protoperidinium oceanicum, indicate the influence of sub-antarctic waters. Fernandes (1992) also observed a bloom of Phaeocystis sp immediately after the diatoms bloom, similar to what occurs in coastal regions of the North Sca (Lancelot et al., 1991).

\section{Phytoplankton assemblages in the shelf off Paraná State}

The accomplished works in the coastal area and in the intermediate shelf allow for the distinguishing of the following phytoplanktonic associations:

a) The coastal assemblage, dominated by diatoms, mainly Pseudonitzschia seriata, Pseudonitzschia delicatissima, Leptocylindrus danicus, Leptocylindrus minimus, Chaetoceros affinis, Chaetoceros debilis, Chaetoceros didymus, Chaetoceros curvisetum, Chaetoceros compressum, Guinardia (=Rhizosolenia) striata, $G$. (=Rhizosolenia) delicatula, Dactyliosolen fragilissimus (=Rhizosolenia fragilissima), Cerataulina bergonii, Hemiaulus hauckii, H. sinensis, Asterionellopsis glacialis, Thalassionema nitzschioides and Skeletonema costatum. Dinoflagellates are less abundant, and numerically dominated by the genus Gymnodinium, Amphidinium, Cochlodinium, Gyrodinium and Torodinium robustum, followed by Ceratium furca, Ceratium fusus, Protoperidinium depressum, Protoperidinium spp, Prorocentrum balticum, Prorocentrum compresum, Prorocentrum micans, Prorocentrum minimum, Podolampas palmipes, Podolampas spinifera, Dinophysis acuminata, Dinophysis caudata, Dinophysis rotundata and Noctiluca miliaris. Occasionally, some of these species may cause blooms. The predominant silicoflagellate is Dictyocha fibula. The coccolithophorids are normally represented by Gephyrocapsa oceanica and Emiliania huxleyii, followed by Anoplosolenia sp, Antosphaera sp, Calciopapus sp, Calciosolenia sp, Corisphaera sp, Crycosphaera sp and Helichosphaera carterae, which occurred in low concentrations.

b) The shelf assemblage, greatly influenced by oligotrophic waters of the Brazil Current, where dinoflagellates are dominated by Ceratium azoricum, $C$. gravidum, C. massiliensis, C. trichoceros, C. vultur, Protoperidinium elegans, Amphisolenia bidentata, 


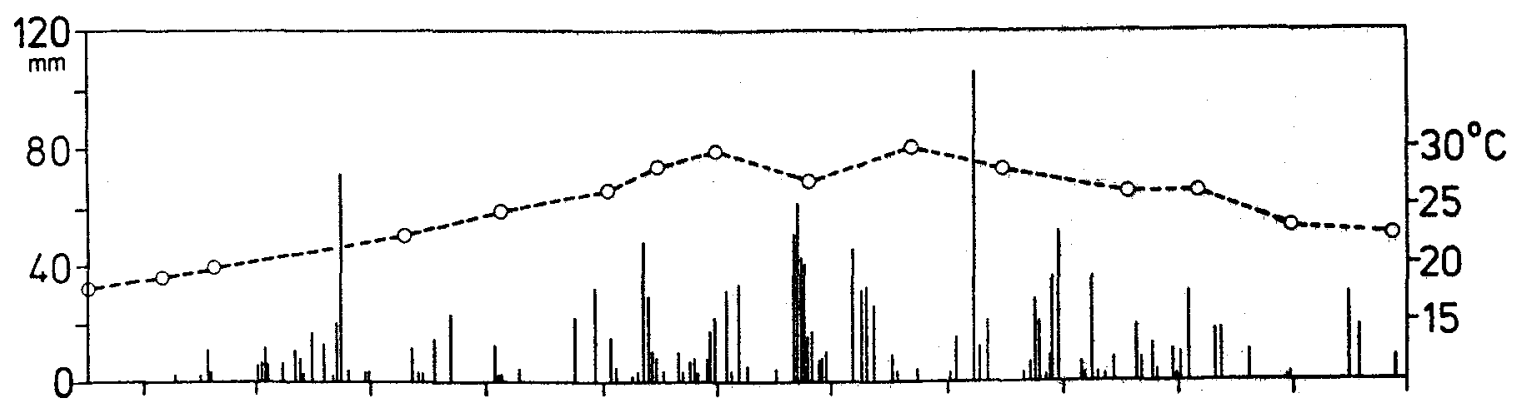

(A)

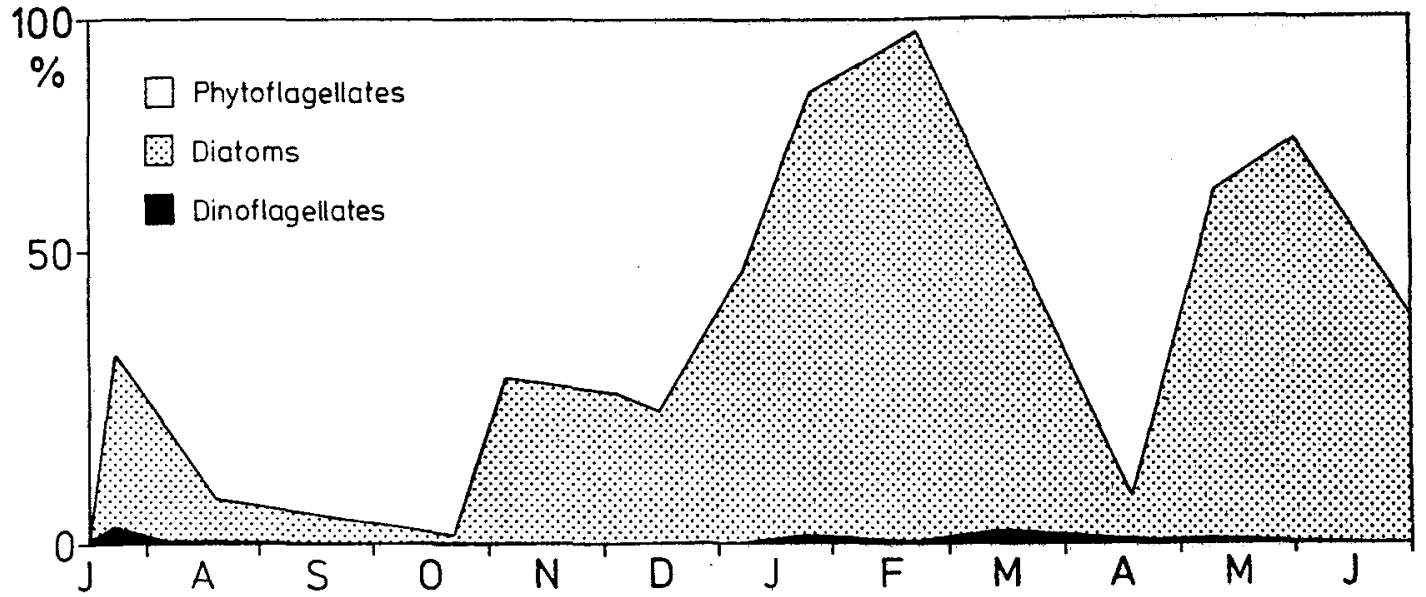

Fig. 5. Precipitation, air temperature $(A)$ and relative abundance of the phytoplanktonic groups $(B)$ at the surface of the Bay of Paranaguá. The figure shows the domain of diatoms in the warmer and rainier periods, and of flagellate forms during winter with less continental drainage (modified from Brandini, 1985a).

Goniodoma poliedricum, Pyrophacus steinii, Gonyaulax spp and Ceratium spp (see review of Balech, 1988). The coccolithophorids are essentially represented by Gephyrocapsa oceanica, Emiliania huxleyii and Umbilicosphaera sibogae. Secondly, occurred the diatoms Climacodium frauenfeldianum, Coscinodiscus gigas, $C$. centralis, Proboscia (=Rhizosolenia) alata, Hemiaulus membranaceus and Fragilariopsis (= Pseudoeunotia) doliolus. The species Gossleriela tropica and Planktoniella sol are rare but always present in net samples. The cyanobacteria Oscillatoria erythraea is common, forming sometimes extensive patches. During summer, these species also occur in inner-shelf regions, being mixed with the coastal assemblage.

\section{Final remarks}

The climatology and the seasonal variation of the oceanographic structure of the region, renders even more complex the space- temporal dynamics of the microalgae communities. Although the studies on the composition and biogeography of microalgal species are more or less advanced, there is missing physioecological data to complement the interpretation of patterns of distribution and development in relation to environmental parameters. From that point on, it will be possible to evalulate quantitatively the role of microalgae in the marine ecosystem on the Parana shelf, and to trace ecological models which will allow to foresee regularities and variations in the community over a longer period of time.

\section{References}

Aidar, E. 1970. O fitoplâncton da Baía de Paranaguá. Relatório apresentado à SUDEPE. (não publicado)

Aidar-Aragão, E.; Tcixeira, C. \& Vieira, A. 1980. Produção primária e concentração de clorofila- $a$ na costa brasileira (Lat. $22^{\circ} 31^{\prime} \mathrm{S}$ - Long. $41^{\circ} 52^{\prime} \mathrm{W}$ a Lat. $28^{\circ} 43^{\prime}$ S - Long $47^{\circ} 57^{\prime} \mathrm{W}$ ). Bolm Inst. oceanogr., S Paulo, 29(2):9-14.

Balcch, E. 1988. Los dinoflagelados del Atlântico Sudoccidental. Publ. Esp. Inst. Esp. Oceanogr., Madrid, 1:310p. 
Bigarella, J. J. 1978. A Serra do Mar e a porção oriental do Estado do Paraná. Um problema de segurança ambiental e nacional. (Contribuições à geografia, geologia e ecologia regional). Curitiba, SEP/ADEA. 249p.

Brandini, F. P. 1985a. Seasonal succession of the phytoplankton in the Bay of Paranaguá (Paraná State - Brazil). Revta bras. Biol., 45(4):687-694.

Brandini, F. P. 1985b. Ecological studies in the Bay of Paranaguá. I. Horizontal distributions and seasonal dynamics of the phytoplankton. Bolm Inst. oceanogr., S Paulo, 33(2):139-147.

Brandini, F. P. 1988a. Hydrography, phytoplankton biomass and photosynthesis in shelf and oceanic waters off Southeastern Brazil during autumn (May/June 1983). Bolm Inst. oceanogr., S Paulo, 36(1/2):63-72.

Brandini, F. P. 1988b. Composição e distribuição do fitoplâncton na Região Sueste e suas relaçōes com as massas d'água (Operação Sueste I - Inverno/1982). Ciênc. Cult., S Paulo, 40(4):334-341.

Brandini, F. P. 1990a. Hydrography and characteristics of the phytoplankton in shelf and oceanic waters off Southeastern Brazil during winter (July/August 1982) and summer (February/March 1984). Hydrobiology, 196(2): 111-148.

Brandini, F. P. 1990b. Produção primária e características fotossintéticas do fitoplâncton na Região Sueste do Brasil. Bolm Inst. oceanogr., S Paulo, 38(2):147-159.

Brandini, F. P. \& Moraes, C. L. B. 1986. Composição e distribuição do fitoplâncton em áreas costeiras e oceânicas da Região Sueste do Brasil. Nerítica, Pontal do Sul, 1(3):9-21.

Brandini, F. P. \& Thamm, C. A. C. 1994. Variações diárias e sazonais do fitoplâncton e parâmetros ambientais na Baía de Paranaguá. Nerítica, Pontal do Sul, 8(1/2):55-72.

Brandini, F. P.; Moraes, C. L. B. \& Thamm, C. A. C. 1989. Shelf-break upwelling, subsurface maxima of chlorophyll and nitrite, and vertical distribution of a subtropical nano-microplankton community off southeastern Brazil. In: Brandini, F. P. ed. Memórias do III Encontro Brasileiro de Plâncton. Caiobá, Paraná. p.47-55.
Brandini, F. P.; Thamm, C. A. H. \& Ventura, I. 1988. Ecological studies in the Bay of Paranagua. III. Seasonal and spatial variations of nutrients and chlorophyll-a. Nerítica, Pontal do Sul, 3(1):1-30.

Cunha, J. A. 1989. Relaçōes entre composição e variação qualitativa relativa genérico/específica, das diatomáceas (Chrysophyta-Bacillariophyceae), no Canal da Galheta, município de Paranaguá, Estado do Paraná, Brasil. Dissertação de mestrado. Universidade Federal do Paraná, Depto de Botânica. 598p.

Deacon, G. E. R. 1933. A general account of the hydrology of the Southern. Atlantic Ocean. Discovery Rep. 7:171-238.

Deacon, G. E. R. 1937. The hydrology of the Southern Ocean. Discovery Rep., 15:1-124.

Defant, A. 1936. Die troposphäre des Atlantischen Ozeans. Wiss. Ergebn. dt. atlant. Exped. "Meteor", 6(1):289-411.

D.H.N. 1980. $71^{\text {a }}$ Comissão Oceanográfica/Operação Conversut I, Costa Sul - Oceanografia Física e Biológica. N/Oc."Almirante Saldanha". Diretoria de Hidrografia e Navegaçāo da Marinha do Brasil. $21 \mathrm{p}$.

D.H.N. 1985. 101 ${ }^{a}$ Comissāo Oceanográfica/Operação Sueste II, Costa Sueste - Oceanografia Física, Química e Biológica. N/Oc."Almirante Saldanha". Diretoria de Hidrografia e Navegaçāo da Marinha do Brasil. $31 p$.

D.H.N. 1986a. 98 Comissão Oceanográfica/Operação Sueste I, Costa Sueste - Oceanografia Física, Química e Biológica. N/Oc."Almirante Saldanha". Diretoria de Hidrografia e Navegação da Marinha do Brasil. $33 p$.

D.H.N. 1986b. 200 Comissão Oceanográfica/Operação Sueste III, Costa Sueste - Oceanografia Física, Química e Biológica. N/Oc."Almirante Saldanha". $31 p$.

D.H.N. 1987. 98a Comissão Oceanográfica/Operação Sueste IV, Costa Sueste - Oceanografia Física, Química e Biológica. N/Oc. "Almirante Saldanha". Diretoria de Hidrografia e Navegação da Marinha do Brasil. 31p. 
D.H.N. 1989. 141" Comissão Oceanográfica/Operação Monitor IV. Costa Sul: Oceanografia Química, Fisica e Biológica. N/Oc. "Almirante Saldanha". Diretoria de Hidrografia e Navegação da Marinha do Brasil. 26p.

Dugdale, R. C. \& Goering, J. J. 1967. Uptake of new and regenerated forms of nitrogen in primary productivity. Limnol. Oceanogr., 12:196-206.

Emilsson, I. 1959. Alguns aspectos físicos e químicos das águas marinhas brasileiras. Ciênc. Cult., S Paulo, 11(2):4454.

Emilsson, I. 1961 The shelf and coastal waters off Southern Brazil. Bolm Inst. oceanogr., S Paulo, 11(2):101-112.

Fernandes, L. F. 1992. Variação sazonal do fitoplâncton e parâmetros hidrográficos em uma estação costeira de Paranaguá - Paraná. Dissertação de mestrado. Universidade Federal do Paraná, Depto de Botânica. 93p.

Freitas, C. A. F. 1989. Parâmetros hidrográficos e fitoplâncton. In: Almeida, C. ed. Estudo biológico integrado da foz da Gamboa do Maciel (Paranaguá Paraná) durante dois ciclos de maré. Universidade Federal do Paraná, Centro de Biologia Marinha, UFPR, p.13-36.

Hubold, G. 1980. Hydrography and plankton off Southern Brazil and Rio de La Plata, August - November 1977. Atlântica, Rio Grande, 4(1):1-22.

Hurt, R. W. \& Blasi, O. 1960. O sambaqui do Macedo. Universidade do Paraná, FFDAA, A52.

Lancelot, C.; Billen, G. \& Barth, H. 1991. The dynamics of Phaeocystis blooms in nutrient enriched coastal zones. Wat. Pollut. Res. Rep., 23:116p.

Matsuura, Y. 1986. Contribuição ao estudo da estrutura oceanográfica da região sudeste entre Cabo Frio (RJ) e Cabo de Santa Marta Grande (SC). Ciênc. Cult., S Paulo, 38:1439-1450.

Mesquita, A. R. de; Leite, J. B. A. \& Rizzo, R. 1983. Note on the shelf break upwelling off the southeast coast of Brazil (Lat. 26 $30^{\circ} \mathrm{S}$ ). Bolm Inst. oceanogr., S Paulo, 32(2):193-198.
Miranda, L. B. de 1982. Análise de massas de água da plataforma continental e da região oceânica adjacente: Cabo de São Tome (RJ) a Ilha de São Sebastião (SP). Dissertação de livre- docência. Universidade de São Paulo, Instituto Oceanográfico. 193p.

Moreira-Filho, H. 1959. Diatomáceas do Paraná: I. A flora diatomológica no Sargassum. Bolm Inst. Hist. nat., curitiba, 2:1-18.

Moreira-Filho, H. 1960. Diatomáceas no trato digestivo de Tegula viridula Gmelin. Bol. Univ. Paraná, 1:1-24.

Moreira-Filho, H. 1961. Diatomáceas da Baía de Guaratuba. Bol. Univ. Paraná, 3:1-33.

Moreira-Filho, H. 1968. Margaritum (Podosira) tenebro (Leudger- Fortmorel) nov.genus et nov.comb. (Chrysophyta- Bacilllariophyceae). Bol. Univ. Fed. Paraná, 20:1-2.

Moreira-Filho, H. \& Fernandes, E. C. L. 1958. Nota preliminar sobre as Bacillariophyceae da Baía de Guaratuba (Paraná). Trib. farm., Curitiba, (6):81-87.

Moreira-Filho, H. \& Kutner, M. B. B. 1962. Contribuição para o conhecimento das diatomáceas do manguezal de Alexandra. Bol. Univ. Paraná, 4:1-24.

Moreira-Filho, H. \& Mômoli, D. M. M. 1962. Sobre a presença de diatomáceas em alguns sambaquis do litoral paranaense. Bol. Univ. Paraná, 5:1-9.

Moreira-Filho, H.; Valente-Moreira, I. M. \& Trippia-Cecy, I. I. 1975. Diatomáceas da Baía de Paranaguá. Bolm Mus. Bot. Munic., 20:1-23.

Moreira-Filho, H.; Valente-Moreira, I. M. \& Matos, A. 1977. Diatomáceas epífitas em Codium decorticatum (Wood.) Howe. Trib. farm., Curitiba, 44(6):3-17

Moreira-Filho, H. \& Valente-Moreira, I. M. 1979. Diatomáceas da enseada da Prainha, Matinhos, Paraná. Bolm Mus. Bot. Munic., 35:1- 12.

Moreira-Filho, H. \& Valente-Moreira, I .M. 1980. Diatomáceas epífitas em Ulva fasciata Delile. Bolm Mus. Bot. Munic., 41:1-10. 
Morcira-Filho, H. \& Valente-Moreira, I. M. 1981. Avaliação taxonômica e ecológica das diatomáceas (Bacillariophyceae) epifitas em algas pluricelulares obtidas nos litorais dos Estados do Paraná, Santa Catarina e São Paulo. Bolm Mus. Bot. Munic., 47:1- 17.

Moreira-Filho, H. \& Valente-Moreira, I. M. 1984. Catálogo das diatomáceas (ChrysophytaBacillariophyceae) marinhas e estuarinas do Estado do Paraná, Brasil. Acta Biol. Par., Curitiba, 13(1,2,3,4):3- 49.

Moreira-Filho, H.; Valente-Moreira, I. M.; Souza-Mosimann, R. M. \& Cunha, J. A. 1990. Avaliação florística e ecológica das diatomáceas (Chrysophyta-Bacillariophyceae) marinhas e estuarinas nos Estados do Paraná, Santa Catarina e Rio Grande do Sul. Est. Biologia, PUC/PR, 25:5-48.

Nimer, E. 1990. Clima. In: Geografia do Brasil. Região Sul. Publ. Inst. bras. Geogr. Estatíst., 2:151-187.

Oliveira, R. J. M. 1983. Um levantamento quantitativo relativo do gênero Actinopthychus Ehrenberg (Chrysophyta-Bacillariophyceae) no estuário do rio Itiberê -Paraná, Brasil. Est. Biologia, PUC/PR, 8:1-27.

Oliveira, R. J. M. 1984. Contribuição ao conhecimento das diatomáceas (Bacillariophyceae) no plâncton estuarino do rio Itiberê, município de Paranaguá, Estado do Paraná, Brasil. Dissertação de mestrado. Universidade Federal do Paraná. 441p.

Paula, J. L. T. M. 1990. Diatomáceas (ChrysophytaBacillariophyceae) epífitas em Centroceras clavulatum (C.Agardh) Montagne (Rhodophyta-Ceramiales) da ilha do Farol, balneário de Caiobá, Paraná, Brasil. Dissertação de mestrado. Universidade Federal do Paraná, Depto de Botânica. 129p.

Rebello, J. \& Brandini, F. P. 1990. Variação temporal de parâmetros hidrográficos e material particulado em suspensão em dois pontos fixos da Baía de Paranaguá, Paraná (junho/87 - fevereiro/88). Nerítica, Pontal do Sul, 5(1):95-111.

Soares, L. F. S. 1983. Estudo do fitoplâncton de águas costeiras e oceânicas da região de Cabo Frio - RJ $\left(23^{\circ} 31^{\prime} \mathrm{S} ; 4^{\circ} 52^{\prime} \mathrm{W}\right)$ até o Cabo de Santa Marta Grande-SC ( $\left.28^{\circ} 43^{\prime} \mathrm{S} 47^{\circ} 57^{\prime} \mathrm{W}\right)$. Dissertação de mestrado. Universidade de São Paulo, Instituto Oceanográfico. 118p.
Steemann-Niclsen, E. 1952. The use of the radioactive carbon (C-14) for measuring organic production in the sea. Rapp. P.-v. Réun. Cons. perm. int. Explor. Mer., 144:38-45.

Valente-Moreira, I. M. 1987. A flórula diatomológica marin : e estuarina nos balneários de Canoas e Ipaner: Estado do Paraná, Brasil. Est. Biologia, PUC/PR, 17:26-48.

Valente-Mc ira, I. M. \& Moreira Filho, H. 1981. Diatomaceas de Pontal do Sul, Município de Paranaguá, Estado do Paraná, Brasil. (Chrysophyta-Bacillariophyceae). Phycol. Lat. Amer. 1:156-185.

Valente-Moreira, I. M.; Moreira Filho, H. \& Cunha, J. A. 1985. Diatomáceas (Bacillariophyceae) marinhas e estuarinas nas praias de Atami e Shangri-lá, Município de Paranaguá, Estado do Paraná, Brasil. Est. Biologia, PUC/PR, 12:1-47.

Valente-Moreira, I. M.; Moreira Filho, H.; Cunha, J. A. \& Shirata, M. T. 1987. A flórula diatomológica marinha e estuarina nos balneários de Canoas e Ipanema, Estado do Paraná, Brasil. I. Estudo qualitativo e ecológico. Est. Biologia, PUC/PR, 17:23-48.

Valente-Moreira, I. M.; Moreira Filho, H.; Cunha, J. A. \& Nakamura, I. T. 1994. Diatomáceas (Chrysophyta-Bacillariophyceae) no conteúdo estomacal de peixes e crustáceos do manguezal do rio Perequê, Pontal do Sul, Estado do Paraná, Brasil. Est. Biologia, PUC/PR, 3(39):99-114.

Vieira, A. A. H. \& Teixeira, C. 1981. Excreção de matéria orgânica dissolvida por populaçōes fitoplanctônicas da costa leste e sudeste do Brasil. Bolm Inst. oceanogr., S Paulo, 30(1):9-25.

Wüst, G. 1932. Das ozeanographische beobachtungsmaterial. Wiss. Ergebn. dt. atlant. Exped. "Meteor", 4(2):290p. December 1995; accepted 20 Marsh 1996) 